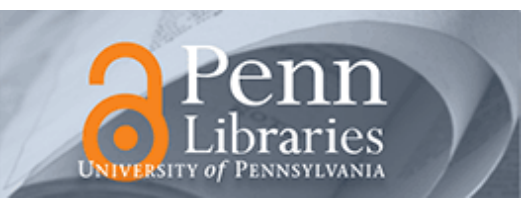

University of Pennsylvania

ScholarlyCommons

\title{
Gender-Math Stereotype, Biased Self-Assessment, and Aspiration in STEM Careers: The Gender Gap among Early Adolescents in China
}

Ran Liu

University of Wisconsin-Madison, ran.liu@wisc.edu

Follow this and additional works at: https://repository.upenn.edu/education_inequality_workshop

Part of the Demography, Population, and Ecology Commons, Gender and Sexuality Commons, and the Inequality and Stratification Commons

\section{Recommended Citation}

Liu, Ran. 2018. "Gender-Math Stereotype, Biased Self-Assessment, and Aspiration in STEM Careers: The Gender Gap among Early Adolescents in China." Penn Education and Inequality Working Papers, \#3. https://repository.upenn.edu/education_inequality_workshop/3

This paper was published in the following journal:

Liu, Ran. 2018. "Gender-Math Stereotype, Biased Self-Assessment, and Aspiration in STEM Careers: The Gender Gap among Early Adolescents in China." Comparative Education Review 62(4):522-541. https://doi.org/10.1086/ 699565.

This paper is posted at ScholarlyCommons. https://repository.upenn.edu/education_inequality_workshop/3 For more information, please contact repository@pobox.upenn.edu. 


\title{
Gender-Math Stereotype, Biased Self-Assessment, and Aspiration in STEM Careers: The Gender Gap among Early Adolescents in China
}

\begin{abstract}
This article explores the paradox between the closing gender gap in math performance and the persistent gender gap in STEM aspiration using data from the Chinese Education Panel Survey (CEPS). Extending the stereotype threat literature, this article includes measures of gender-math stereotypes from students, parents, and peers, and offers an analysis to address the limitations of previous studies. Findings indicate that gender-math stereotypes are associated with a gender gap in students' self-assessment in mathlearning competency, even after controlling for math performance; this self-assessment is further associated with students' aspiration in science and engineering careers. Moreover, the effect of math self-assessment on science and engineering aspiration is stronger among girls than boys. However, even after controlling for math self-assessment and gender-math stereotype, boys are still more likely to aspire to careers in science and engineering than girls. This article discusses policy implications of the findings.
\end{abstract}

\section{Keywords}

Chinese Education Panel Survey (CEPS), STEM education, gender gap, stereotypes, careers, self evaluation, mathematics

\section{Disciplines}

Demography, Population, and Ecology | Gender and Sexuality | Inequality and Stratification | Social and Behavioral Sciences | Sociology

\section{Comments}

This paper was published in the following journal:

Liu, Ran. 2018. "Gender-Math Stereotype, Biased Self-Assessment, and Aspiration in STEM Careers: The Gender Gap among Early Adolescents in China." Comparative Education Review 62(4):522-541. https://doi.org/10.1086/699565. 


\title{
Gender-Math Stereotype, Biased Self-Assessment, and Aspiration in STEM Careers: The Gender Gap among Early Adolescents in China
}

\author{
RAN LIU
}

\begin{abstract}
This article explores the paradox between the closing gender gap in math performance and the persistent gender gap in STEM aspiration using data from the Chinese Education Panel Survey (CEPS). Extending the stereotype threat literature, this article includes measures of gender-math stereotypes from students, parents, and peers, and offers an analysis to address the limitations of previous studies. Findings indicate that gender-math stereotypes are associated with a gender gap in students' self-assessment in math-learning competency, even after controlling for math performance; this selfassessment is further associated with students' aspiration in science and engineering careers. Moreover, the effect of math self-assessment on science and engineering aspiration is stronger among girls than boys. However, even after controlling for math selfassessment and gender-math stereotype, boys are still more likely to aspire to careers in science and engineering than girls. This article discusses policy implications of the findings.
\end{abstract}

\section{Introduction}

The underrepresentation of women in science, technology, engineering, and math (STEM) fields persists around the world despite the progress of gender equality in overall educational attainment (Riegle-Crumb et al. 2011; OECD 2015; NSF 2016). This gender segregation in education and workforce has at least two unfavorable consequences: first, it is highly relevant to gender income inequality since STEM fields tend to be more lucrative (Maple and Stage 1991; Trusty et al. 2000); second, it reflects the underuse of valuable human resources in an era of increasing demand of skilled STEM workers (Perry et al. 2012).

Studies using US and cross-national data find that aspiration in STEM careers is associated with math performance at school. ${ }^{1}$ However, while

\footnotetext{
${ }^{1}$ For the US cases, see Xie and Shauman (2003), Correll (2004), and Riegle-Crumb et al. (2011). For cross-national analysis using the PISA data, see Mann et al. (2015).

Received December 19, 2016; revised June 30, 2017, March 1, 2018, and June 1, 2018; accepted June 4, 2018; electronically published August 24, 2018

Comparative Education Review, vol. 62, no. 4.

(C) 2018 by the Comparative and International Education Society. All rights reserved.

0010-4086/2018/6204-0041\$10.00
} 
studies using cross-national data sets such as the Programme for International Student Assessment (PISA) and Trends in International Mathematics and Science Study (TIMSS) show that the gender gap in math performance has been decreasing or disappearing in recent years (Mullis et al. 2015; OECD 2015), the gender gap in aspiration for STEM majors and careers has remained large around the world (OECD 2015; Mann and DiPrete 2016), leading to a paradox between the closing gender gap in math performance and the persistent gender gap in STEM aspiration.

Stereotype threat theory provides one important perspective to understand this paradox. It argues that negative stereotypes undermine the performance of members in the stereotyped group by exerting an interfering pressure - the pressure that one's performance might be seen as confirming the stereotypes. Therefore, exposure to the gender-math stereotype (or the belief that boys are born better than girls at math) undermines female students' math performance. ${ }^{2}$

However, the stereotype threat literature suffers from three important limitations when explaining the gender gap in STEM career aspiration. First, it relies on either experimental or macrolevel data while rarely having access to measures of individual endorsement of gender-math stereotype at a generalizable scale. Second, it mainly focuses on the direct effect of gender stereotype on math performance while rarely examining the consequences of stereotype on students' attitudes, such as self-assessment and career aspirations. Third, it fails to identify the sources of gender stereotype, for example, whether the stereotypes are from students themselves, their parents, or peers; as a result, it fails to distinguish the consequences of stereotypes from different sources.

Extending stereotype threat theory, this article examines whether the gender-math stereotype is associated with gender gaps in students' math selfassessment and career aspirations. Using data from the Chinese Education Panel Survey (CEPS), this article incorporates measures of gender-math stereotype from students, parents, and peers into the analysis to address the limitations of the stereotype threat literature. It focuses on the following research questions: (1) Is the gender-math stereotype from students, parents, and peers associated with students' self-assessment in math-learning competency, controlling for math performance? (2) Is the gender-math stereotype from students, parents, and peers further associated with students' aspiration for science and engineering careers, controlling for math performance? (3) Is students' self-assessment in math associated with their aspiration for science and engineering careers, controlling for math performance?

\footnotetext{
${ }^{2}$ See Spencer et al. (1999), Good et al. (2008), Nguyen and Ryan (2008), and Thoman et al. (2008).
} 


\section{Background}

Gender Gaps in Math Performance and STEM Aspirations

Women have been consistently underrepresented in STEM fields around the world. ${ }^{3}$ Using country-level data on college graduates' majors, Charles and Bradley (2009) show universal underrepresentation of women in engineering programs in 44 countries. In the United States, women accounted for 39, 41, and 32 percent of those with highest STEM degrees at the bachelor's, master's, and doctoral levels, respectively (NSF 2016). Among East Asian countries, women earned only 26 percent of the science and engineering bachelor's degrees in Taiwan, 28 percent in Japan, and 30 percent in South Korea (NSF 2016).

Many studies suggest that the gender gap in STEM fields can be traced back to gender differences in math performance in early school years. ${ }^{4}$ However, recent research generally finds no gender difference or a slight female advantage in math performance among young adolescents. For example, according to the 2015 TIMSS data, among eighth grade students, only six countries out of 39 had gender differences that favored boys, seven countries had gender differences that favored girls, while 26 countries had no gender differences in math achievements (Mullis et al. 2015). Gender differences in math performance in East Asian countries are particularly small and even nonexistent in China (Tsui 2007; Mullis et al. 2015; OECD 2015).

On the other hand, studies consistently show that females are less interested in STEM education and occupation than males around the world. ${ }^{5}$ For example, the PISA 2012 data show that there are almost four times as many boys as girls who aspire for a career in engineering in OECD countries and close to three times as many boys as girls in other participating countries (OECD 2015). This shows that there must be other factors besides math performance contributing to the persistent gender gap in STEM aspiration.

Stereotype Threat Theory

Stereotype threat theory provides one important perspective to understand the paradox between the closing gender gap in math performance and the persistent gender gap in STEM aspiration. It argues that widely shared cultural beliefs in the superiority of one group over another create a psychological threat that directly disadvantages the individuals experiencing discrimination (Steele and Aronson 1995; Spencer et al. 1999). Scholars have found consistent stereotypes about male and female personality and ability

\footnotetext{
${ }^{3}$ See Xie and Shauman (2003), Riegle-Crumb et al. (2011), OECD (2015), and NSF (2016).

${ }^{4}$ For US studies, see Eccles et al. (1990), Xie and Shauman (2003), Correll (2004), and RiegleCrumb et al. (2011). For a cross-national study using the PISA data, see OECD (2015).

${ }^{5}$ For US studies, see Xie and Shauman (2003), Correll (2004), and Riegle-Crumb et al. (2011). For cross-national studies, see Sikora and Pokropek (2012), Charles et al. (2014), OECD (2015), and Mann and DiPrete (2016);
} 
across different societies. For example, Williams and Best (1990) conducted a cross-cultural study covering 25 countries in Europe, Asia, Africa, Oceania, and the Americas, revealing that in virtually all participant countries, females are believed to be better at nurturing and caring tasks, while males are viewed as more analytical and logical. In particular, there has been a widespread gender-math stereotype that regards math as masculine and believes that males have higher competency than females in mathematical tasks (Eccles et al. 1990; Spencer et al. 1999; Lueptow et al. 2001).

Studies using experimental data find that gender stereotypes can indeed affect students' math performance. ${ }^{6}$ A meta-analysis of stereotype threat literature from 1999 to 2006 finds that in experimental settings, women experience significant decline in test performance when exposed to gender stereotypes (Nguyen and Ryan 2008). Spencer et al. (1999) show that the gender gap in math performance disappears when the test administrator lowers the stereotype threat by describing the test as not producing gender differences. Scholars using cross-national data also find that national-level stereotypes are associated with gender gaps in students' science and math achievements (Nosek et al. 2009).

However, stereotype threat literature has three important limitations. First, previous studies rarely have access to measures of individual endorsement of the gender-math stereotype at a large, generalizable scale. Therefore, they tend to either use experimental data with small-sample test takers or national-level data, failing to capture the details in students' experiences at home and school.

Second, previous studies mostly focus on the effect of stereotype on students' math performance, therefore failing to explain the paradox between the closing gender gap in math performance and the persistent gender gap in STEM aspiration. One exception is the Correll study (2004), which demonstrates the consequences of stereotype on self-assessment and aspiration among US students. The gender stereotype measures in Correll (2004), however, are from an experimental setting. In fact, studies consistently find that boys tend to have higher self-assessment in math in the United States (Correll 2004; Riegle-Crumb et al. 2011) and many other countries (Sikora and Pokropek 2012). However, it is not yet clear how gender stereotypes may contribute to the gender gaps in students' self-assessment and career aspirations, especially in a non-US context.

Third, due to the limitation in measurements, previous studies seldom identify the sources of the gender-math stereotype, for example, whether the stereotype is from students, parents, or peers. Earlier studies from the United

\footnotetext{
${ }^{6}$ For some examples of the effect of gender stereotype on females' math performance, see Spencer et al. (1999), Good et al. (2008), Nguyen and Ryan (2008), Thoman et al. (2008), and Miller et al. (2015).
} 
States demonstrate that students may adjust their own expectations and behaviors according to parental expectations (Eccles and Jacobs 1986; Eccles et al. 1990). Peers' behaviors can also influence students' attitudes and behaviors through various mechanisms, such as model similarity (Schunk 1987) and peer networks (Dweck and Goetz 1978). Therefore, it is reasonable to hypothesize that stereotypes from parents and peers may affect students' selfassessment and aspiration, and it is crucial to distinguish the sources of such stereotypes.

The CEPS data provide a valuable opportunity to address the limitations of the stereotype threat literature for three reasons. First, it includes questions directly asking students and parents whether they endorse the gendermath stereotype, providing an actual measurement of the gender-math stereotype at home and school. Second, it includes questions about students' math self-assessment and career aspiration, allowing examination of the effect of gender-math stereotype on these two outcomes. Third, China presents a unique social context to study gender stereotypes and gender gaps in STEM career aspiration, which will be explained in the next section.

\section{The Chinese Context}

When studying gender gaps in STEM education, China presents a particularly interesting context for three reasons. First, China has a long history under the influence of traditional Confucian values that emphasize distinct gender roles (Li and Lavely 2003; Granrose 2007; Liu 2014). The socialist period witnessed dramatic changes as the Chinese government made efforts promoting gender egalitarian practices; however, this progress has slowed down since the late 1970s (Hannum and Xie 1994; Liu 2014). Recent evidence still exhibits great gender inequality and gendered norms in Chinese society (Croll 2000; Li and Lavely 2003; Hannum et al. 2009). Studies also show significant occupational gender segregation in contemporary China. Male employees are disproportionately distributed in more lucrative jobs than women (Summerfield et al. 2011; Xiu and Gunderson 2015), and this occupational segregation plays an important role in creating gender earning gaps (Summerfield et al. 2011; He and Wu 2017). Therefore, China provides an important context for studying the association between gender stereotypes and occupational segregation.

Second, the gender gap in math performance is found to be low or nonexistent among Chinese young adolescents (Tsui 2007; OECD 2015), presenting a particularly interesting case of the paradox between math performance and STEM aspiration. For example, the PISA 2015 results show that in mainland Chinese cities (Shanghai, Guangdong, and Beijing), girls achieve the same level of math performance as boys. Using a local data set from Wuhan, China, Tsui (2007) also finds no gender differences in mean college entrance examination math scores among high school seniors. 
Third, compared to the United States and many other countries, China has a highly standardized secondary education system, especially in the mathematics curriculum, which helps to control for noncultural factors (Tsui 2007; Ayalon and Livneh 2013). In China, math is a mandatory course with a universal national curriculum; it is taught at virtually the same level to all students in elementary and middle schools (Tsui 2007). Therefore, before students step into different academic streams in high school, there are minimal differences between boys and girls in math participation and exposure at school, which helps to control for institutional factors.

Using the CEPS data, I first examine whether student's math self-assessment is associated with math-gender stereotype from students, parents, and peers. I then examine whether gender-math stereotype and math self-assessment are associated with the gender gap in career aspiration.

\section{Data and Method}

Data Set

This study employs the baseline survey of CEPS, a nationally representative survey with approximately 20,000 students in 112 schools of 28 counties in mainland China, completed in the 2013-14 academic year with students in seventh and ninth grades. The survey team administered questionnaires to students, parents, teachers, and school administrators. Only cases with complete information on all variables at all stages of this study are included, resulting in 17,311 valid cases. ${ }^{7}$

\section{Variables}

Dependent variables.-Two dependent variables are used in this analysis. The first variable, self-assessment in math-learning competency is measured by the question "do you find it difficult to study math at the current level?" The answer is on a four-level scale; a larger value corresponds to a higher selfassessment. This ordinal variable is treated as continuous in the analysis to facilitate interpretation. ${ }^{8}$

The second dependent variable, aspiration in science and engineering, is measured by the question "what do you want to do in the future?" Ten occupation categories are provided in the answer to this question: (1) government officials; (2) corporate managers; (3) scientists or engineers; (4) teachers, doctors, or lawyers; (5) designers; (6) artist performers; (7) professional

\footnotetext{
${ }^{7}$ Missing data are less than 4.2 percent for each variable. Models were also run on the entire sample to check for biases due to missing data using the maximum likelihood method, and no substantive differences in the relative magnitude or significance of estimates were found.

${ }^{8}$ The same set of analysis has been performed using ordinal logistic regression models treating the self-assessment variable as an ordinal variable, and no substantial difference in the magnitude or significance of estimates were found in the variables at interest.
} 
athletes; (8) technicians, including drivers; (9) other; and (10) it doesn't matter. This dichotomous variable is coded as 1 if the student chooses "(3) scientists or engineers" and 0 otherwise.

Other control variables.-Parents' highest education is included as a control variable and measured by father or mother's highest education level. The answers are recoded into the International Standard Classification of Education (ISCED) levels and then converted into number of years based on the procedure suggested by PISA (OECD 2014, 444).

In addition, I control for access to computer at home (coded $0=$ no, $1=$ yes $)$ and whether the child has his or her own desk at home (coded $0=$ no, $1=$ yes) as supplemental measures of home education resources. Other individuallevel control variables include grade (seventh or ninth grade), time spent on homework (hours per week), whether parents are absent, and whether the student is an only child, a migrant child, having rural residence status or not.

School-level control variables are added to control for institutional differences, including school ranking in the county, percentage of students with rural residence, percentage of students with local residence, percentage of students with both parents not home, and whether the school is a public school, a boarding school, and located in an urban area.

Models

Two-level random intercepts models are used to predict students' selfassessment in math-learning competency and aspiration in science and engineering. A random intercepts model is a multi-level model that allows intercepts to vary across groups. Random intercepts models are used here because students are clustered in schools; thus the observations are not independent from each other. Estimations without correction for clustering would result in biased standard errors. Random intercepts models help address this issue by including random intercepts at the school level, accounting for differences produced by school characteristics (Aguinis et al. 2013). Individual sampling weights are used in the analysis.

To predict student's math self-assessment, linear regression models with random intercepts are used. The equations at the student level (level 1) and school level (level 2) for the model with one stereotype variable and its interaction with gender can be written as:

Level 1: Assessment $_{i j}=\beta_{0 j}+\beta_{1}$ Female $_{i j}+\beta_{2}$ Midterm $_{i j}+\beta_{3}$ Stereotype $_{i j}$

$$
+\beta_{4} \text { Female }_{*} \text { Stereotype }_{i j}+\alpha \text { Student Controls }_{i j}+\epsilon_{i j}
$$

Level 2: $\beta_{0 j}=\gamma_{00}+\gamma_{01}$ School Controls $j+\mu_{0 j}$

At level 1, Assessment is each students' self-assessment in math-learning competency, $\beta_{0 j}$ is the random intercept that varies across schools, $\beta_{1}$ es- 
timates the main effect of being female, $\beta_{2}$ estimates the effect of midterm math score, $\beta_{3}$ estimates the main effect of stereotype, $\beta_{4}$ estimates the interaction effect between gender and stereotype, $\alpha$ is a vector measuring the effect of other control variables at the student level, and $\epsilon_{i j}$ is the error term. At level 2, $\gamma_{00}$ is the overall intercept, $\gamma_{01}$ is a vector of coefficients for schoollevel control variables, and $\mu_{0 j}$ refers to the random error component for the deviation of school intercept from the overall intercept.

To predict student's aspiration in science and engineering, logistic regression models with random intercepts are used. The equations with one stereotype variable and its interaction with gender can be written as:

$$
\begin{aligned}
& \text { Level 1: } \log \left(\frac{\text { Aspiration }_{i j}}{1-\text { Aspiration }_{i j}}\right)=\beta_{0 j}=\beta_{1} \text { Female }_{i j}+\beta_{2} \text { Midterm }_{i j} \\
& +\beta_{3} \text { Assessment }_{i j}+\beta_{4} \text { Stereotype }_{i j} \\
& +\beta_{5} \text { Female } * \text { Stereotype }{ }_{i j} \\
& +\alpha \text { Student Controls }_{i j}+\epsilon_{i j}
\end{aligned}
$$

Level 2: $\beta_{0 j}=\gamma_{00}+\gamma_{01}$ School Controls $_{j}+\mu_{0 j}$

At level 1, Aspiration is a dichotomous variable measuring whether a student aspires to science and engineering careers, $\beta_{0 j}$ is the random intercept that varies across schools, $\beta_{1}$ estimates the main effect of being female, $\beta_{2}$ estimates the effect of midterm math score, $\beta_{3}$ estimates the effect of selfassessment in math, $\beta_{4}$ estimates the main effect of stereotype, and $\beta_{5}$ estimates the interaction effect between gender and stereotype. The meanings of $\alpha, \epsilon_{i j}$, and the level-2 equation stay the same as in the previous models. ${ }^{9}$

\section{Findings}

\section{Descriptive Statistics}

Table 1 shows the descriptive statistics for all variables. Approximately 48.4 percent of the students are female, 49.8 percent are in grade 9 , and 8.1 percent aspire to become scientists or engineers. Results also show the extensive presence of the gender-math stereotype: more than half of the students (55.3 percent) and 42.5 percent of the parents endorse such stereotype.

Using a two-tailed $t$-test on group means, we observe significant gender differences. Girls tend to achieve higher midterm scores in all three subjects;

\footnotetext{
${ }^{9}$ The random intercepts model assumes that only the intercept varies while the slopes are consistent across groups. A set of random slopes models that allows the slopes of gender and stereotype to vary is also fit to the data. A set of chi-square tests shows that the random intercepts models are a better fit.
} 
TABLE 1

Estimated Mean of Variables for Boys, Girls, and All Students in the Sample

\begin{tabular}{|c|c|c|c|c|}
\hline & All & Male & Female & $\begin{array}{c}\text { Mean } \\
\text { Difference }\end{array}$ \\
\hline Female & $.484(.500)$ & & & \\
\hline \multicolumn{5}{|l|}{ Midterm scores: } \\
\hline Math & $70.340(9.795)$ & $69.801(10.060)$ & $70.915(9.444)$ & $-1.114^{* * *}$ \\
\hline Chinese & $70.327(9.664)$ & $67.554(10.007)$ & $73.284(8.260)$ & $-5.730^{* * *}$ \\
\hline English & $70.299(9.775)$ & $67.613(10.063)$ & $73.165(8.521)$ & $-5.552^{* * *}$ \\
\hline Cognitive ability test score & $.035(.850)$ & $.030(.859)$ & $.040(.843)$ & -.010 \\
\hline \multicolumn{5}{|l|}{$\begin{array}{l}\text { Self-assessment in learning } \\
\text { competency: }\end{array}$} \\
\hline Math & $2.319(.914)$ & $2.416(.936)$ & $2.216(.876)$ & $.200^{* * *}$ \\
\hline Chinese & $2.678(.789)$ & $2.556(.799)$ & $2.807(.753)$ & $-.251^{* * *}$ \\
\hline English & $2.329(.980)$ & $2.115(.964)$ & $2.558(.943)$ & $-.443^{* * *}$ \\
\hline \multicolumn{5}{|l|}{ Gender-math stereotype: } \\
\hline Students & $.553(.497)$ & $.600(.484)$ & $.504(.507)$ & $.096^{* * *}$ \\
\hline Parents & $.425(.494)$ & $.455(.491)$ & $.393(.495)$ & $.062^{* * *}$ \\
\hline Classmates & $.553(.138)$ & $.552(.137)$ & $.552(.139)$ & 0 \\
\hline $\begin{array}{l}\text { Aspiration in science/ } \\
\text { engineering }\end{array}$ & $.081(.273)$ & $.136(.339)$ & $.022(.148)$ & $.114^{* * *}$ \\
\hline \multicolumn{5}{|l|}{$\begin{array}{l}\text { Individual-level control } \\
\text { variables: }\end{array}$} \\
\hline Grade 9 & $.498(.500)$ & $.492(.493)$ & $.504(.507)$ & -.012 \\
\hline Time spent on homework & $5.616(4.089)$ & $5.340(4.043)$ & $5.911(4.116)$ & $-.571^{* * *}$ \\
\hline Migrant children & $.174(.379)$ & $.178(.378)$ & $.169(.380)$ & .009 \\
\hline Ethnic minority & $.080(.272)$ & $.077(.263)$ & $.084(.282)$ & -.007 \\
\hline Rural residency & $.551(.497)$ & $.554(.490)$ & $.547(.505)$ & .007 \\
\hline Only child & $.441(.496)$ & $.479(.493)$ & $.399(.497)$ & $.080^{* * *}$ \\
\hline $\begin{array}{l}\text { Parent's highest education } \\
\text { (years) }\end{array}$ & $10.858(3.028)$ & $10.832(3.001)$ & $10.885(3.056)$ & -.023 \\
\hline $\begin{array}{l}\text { Access to computer } \\
\text { at home }\end{array}$ & $.696(.460)$ & $.695(.455)$ & $.697(.466)$ & -.002 \\
\hline $\begin{array}{l}\text { Access to own desk } \\
\text { at home }\end{array}$ & $.784(.411)$ & $.775(.412)$ & $.794(.410)$ & $-.019^{*}$ \\
\hline Both parents at home & $.771(.420)$ & $.762(.420)$ & $.781(.419)$ & $-.019^{* *}$ \\
\hline \multicolumn{5}{|l|}{$\begin{array}{l}\text { School-level control } \\
\text { variables: }\end{array}$} \\
\hline $\begin{array}{l}\text { Percentage of nonmigrant } \\
\text { students }\end{array}$ & $.824(.188)$ & $.821(.189)$ & $.827(.186)$ & -.006 \\
\hline $\begin{array}{l}\text { Percentage of rural } \\
\text { students }\end{array}$ & $.549(.278)$ & $.552(.274)$ & $.545(.283)$ & .007 \\
\hline $\begin{array}{l}\text { Percentage of parents-not- } \\
\text { home students }\end{array}$ & & & & \\
\hline $\begin{array}{l}\text { home stude } \\
\text { Public school }\end{array}$ & $\begin{array}{l}.231(.155) \\
929(.256)\end{array}$ & $\begin{array}{l}.233(.153) \\
918(.271)\end{array}$ & $\begin{array}{l}.229(.156) \\
.942(.237)\end{array}$ & $\begin{array}{c}.004 \\
-.024^{* *}\end{array}$ \\
\hline School rank & $3.954(.828)$ & $3.950(.822)$ & $3.959(.834)$ & -.009 \\
\hline Boarding school & $2.210(.751)$ & $2.201(.745)$ & $2.219(.756)$ & -.018 \\
\hline Urban location & $.385(.487)$ & $.382(.479)$ & $.387(.494)$ & -.005 \\
\hline Number of observations & 17,311 & 8,611 & 8,700 & \\
\hline
\end{tabular}


correspondingly, they tend to have higher self-assessment in Chinese and English. However, although girls on average also get significantly higher midterm scores in mathematics (girls' mean $=70.915$, boys' mean $=69.801$ ), they report significantly lower self-assessment on math-learning competencies (girls' mean $=2.216$, boys' mean $=2.416$ ). The cognitive ability test, on the other hand, shows no significant gender differences.

In addition, a significantly higher proportion of boys (13.6 percent) than girls (2.2 percent) exhibit the aspiration to become scientists or engineers. A higher percentage of boys (60.0 percent) endorse the gender-math stereotype than girls (50.4 percent); similarly, a higher percentage of boys' parents (45.5 percent) endorse such stereotype than girls' parents (39.3 percent).

Predicting Self-Assessment of Math-Learning Competency

Table 2 shows the results from two-level random intercepts linear models predicting self-assessment of math-learning competency. In the base model (model 1), the significant gender effect $(\beta=-0.171)$ demonstrates that girls

TABLE 2

Random Effects Models Predicting Self-Assessment in Math-Learning Competency

\begin{tabular}{|c|c|c|c|c|c|}
\hline & Model 1 & Model 2 & Model 3 & Model 4 & Model 5 \\
\hline Female & $\begin{array}{l}-.171^{* * *} \\
(.014)\end{array}$ & $\begin{array}{l}.256^{* *} \\
(.083)\end{array}$ & $\begin{array}{l}.073^{* * *} \\
(.019)\end{array}$ & $\begin{array}{l}-.046^{* *} \\
(.016)\end{array}$ & $\begin{aligned}-.040 \\
(.051)\end{aligned}$ \\
\hline Midterm math score & $\begin{array}{l}.046^{* * *} \\
(.001)\end{array}$ & $\begin{array}{l}.048^{* * *} \\
(.001)\end{array}$ & $\begin{array}{l}.043^{* * *} \\
(.001)\end{array}$ & $\begin{array}{l}.044^{* * *} \\
(.001)\end{array}$ & $\begin{array}{l}.045^{* * *} \\
(.001)\end{array}$ \\
\hline Female $\times$ Midterm math score & & $\begin{array}{l}-.006^{* * *} \\
(.001)\end{array}$ & & & \\
\hline Student's stereotype & & & $\begin{array}{l}.177^{* * *} \\
(.017)\end{array}$ & & \\
\hline Female $\times$ student's stereotype & & & $\begin{array}{l}-.465^{* * *} \\
(.025)\end{array}$ & & \\
\hline Parent's stereotype & & & & $\begin{array}{l}.123^{* * *} \\
(.017)\end{array}$ & \\
\hline Female $\times$ parent's stereotype & & & & $\begin{array}{l}-.309^{* * *} \\
(.026)\end{array}$ & \\
\hline Classmates' stereotype & & & & & $\begin{array}{l}.109 \\
(.095)\end{array}$ \\
\hline Female $\times$ classmates' stereotype & & & & & $\begin{array}{l}-.237^{* *} \\
(.087)\end{array}$ \\
\hline Individual-level control variables & Yes & Yes & Yes & Yes & Yes \\
\hline School-level control variables & Yes & Yes & Yes & Yes & Yes \\
\hline Observations & 17,311 & 17,311 & 17,311 & 17,311 & 17,311 \\
\hline
\end{tabular}

Note.-Standard errors in parentheses.

Source.-China Education Panel Survey (CEPS). Dependent variable is students' self-assessment in mathlearning competency. Individual-level survey weights are used in all models. Model 1 is the base model with female and midterm math score as the independent variables; model 2 adds the interaction between female and midterm math score to model 1; model 3 adds student's stereotype and its interaction with female to model 1; model 4 adds parent's stereotype and its interaction with female to model 1; model 5 adds classmate's stereotype and its interaction with female to model 1 . Control variables at the individual and school level are included in all models but omitted from the table.

$* P<.05$.

** $P<.01$.

*** $P<.001$. 
indeed have lower self-assessment than boys, even after controlling for midterm math scores. The positive effect of midterm performance $(\beta=0.046)$ demonstrates that math self-assessment increases with increasing math scores.

Correll (2001) finds that the effect of math test scores is stronger among girls than boys in the United States, suggesting that compared to boys, girls may rely more on performance feedback to develop their math self-assessment. To test for this, model 2 adds the interaction term between gender and math midterm score into the base model. After adding the interaction term, the main effect of the female variable becomes significantly positive $(\beta=0.256)$, while the interaction effect is significantly negative $(\beta=-0.006)$; this shows that among students whose math midterm scores are lower than 42.67 (0.256/ 0.006), female students have a higher self-assessment than males. The negative interaction effect further demonstrates that contrary to Correll (2001), the effect of math scores on self-assessment is smaller for girls than boys in China. This means that while both male and female self-assessment increases with testscores, female self-assessment increases less rapidly than male self-assessment. As a result, although the gender gap in self-assessment favors females among low performers, the gap reverses to favor males and widens as math scores increase. This may imply that negative stereotypical messages counteract positive achievement effects for girls.

The next three models estimate the effect of the gender-math stereotype from students, parents, and peers on math self-assessment. Model 3 adds student-reported stereotype, model 4 adds parent-reported stereotype, and model 5 adds classmates' stereotype to the base model. Each model also adds the interaction term between the stereotype variable and its interaction with gender to test whether the gender gap varies according to the stereotype variable.

After adding the interaction terms, the main coefficient of the female variable exhibits the gender gap among students who are not exposed to the stereotype, and the sum of coefficients of the female variable and the interaction term represents the gender gap among students who are exposed to such stereotype. For example, model 3 shows that among students who do not endorse the gender-math stereotype, girls report higher self-assessment than boys $(\beta=0.073)$. In contrast, girls who endorse the gender-math stereotype report lower self-assessment than boys $(\beta=0.073-0.465=$ $-0.392)$. Model 4 shows that among students whose parents do not endorse the gender-math stereotype, the gender gap in self-assessment is much smaller $(\beta=-0.046)$ compared to students whose parents endorse the gender-math stereotype $(\beta=-0.046-0.309=-0.355)$.

Figures 1 and 2 show the marginal effects of students' and parents' stereotype on math self-assessment by gender, based on model 3 and 4 respectively. Figure 1 shows that the gender gap in self-assessment favors females among students who do not endorse gender-math stereotype. Figure 2 shows 


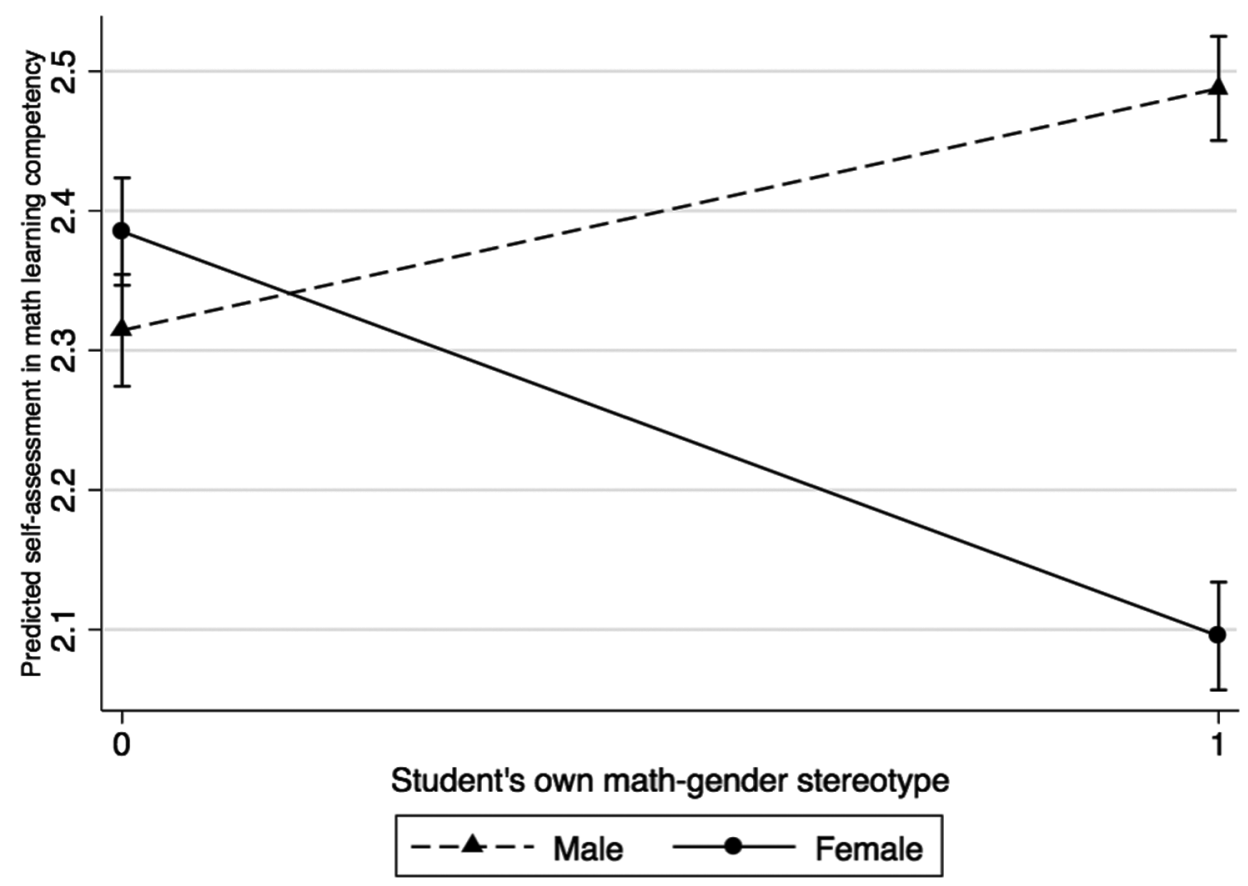

FIG. 1.-Marginal effect of student's gender-math stereotype on self-assessment in math learning competency by gender with $95 \%$ confidence interval. SourCE.-China Education Panel Survey (CEPS). This figure is based on model 2 of table 2.

that the gender gap favoring boys is much smaller among students whose parents do not endorse the gender-math stereotype compared to those whose parents endorse such stereotype.

The classmates' stereotype variable represents the percentage of classmates endorsing the gender-math stereotype. In model 5, the main effects are not significant. However, the significant coefficient of the interaction term $(\beta=-0.237)$ shows a crossover interaction effect, meaning there are predictably opposite effects of classmates' stereotype for boys and girls: boys with more classmates endorsing the gender-math stereotype report higher self-assessment, while girls with more classmates endorsing such stereotype report lower self-assessment. Therefore, a higher percentage of classmates with the gender-math stereotype would result in a larger gender gap in selfassessment.

Figure 3, based on model 5, clearly shows the pattern: for students with fewer classmates endorsing the gender-math stereotype, there is no significant gender gap in self-assessment; as the percentage of classmates having 


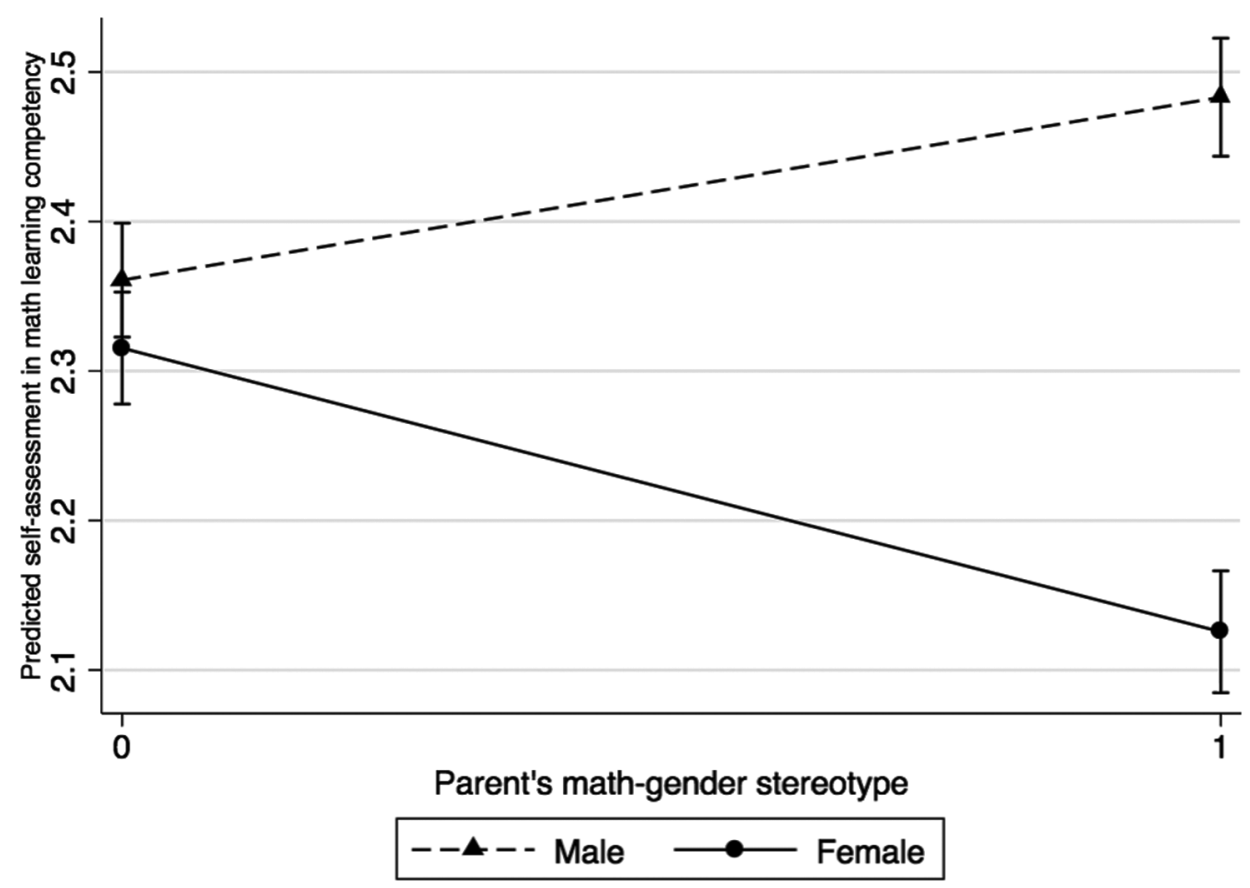

FIG. 2.-Marginal effect of parent's gender-math stereotype on self-assessment in math learning competency by gender with $95 \%$ confidence interval. SourCE.-China Education Panel Survey (CEPS). This figure is based on model 3 of table 2.

such stereotype increases, the gender gap in self-assessment emerges and widens.

\section{Predicting Aspiration in Science and Engineering}

Table 3 shows the results from two-level random intercepts logistic regression models predicting students' aspirations in becoming scientists or engineers. Model 1 is the base model with gender, math midterm score, and math self-assessment as independent variables at the student level. Model 2 adds the interaction term between math self-assessment and gender to test whether the effect of math self-assessment is different for boys and girls. Model 3, 4, and 5 add the stereotype measures and their interactions with gender to test whether the gender gap in aspiration varies according to the stereotype variables.

Across all models, the significant effect of gender shows that girls are less likely to aspire to careers as scientists or engineers, and the significantly positive effect of math midterm score shows that students with higher math performance are more likely to aspire to such careers. Moreover, math self- 


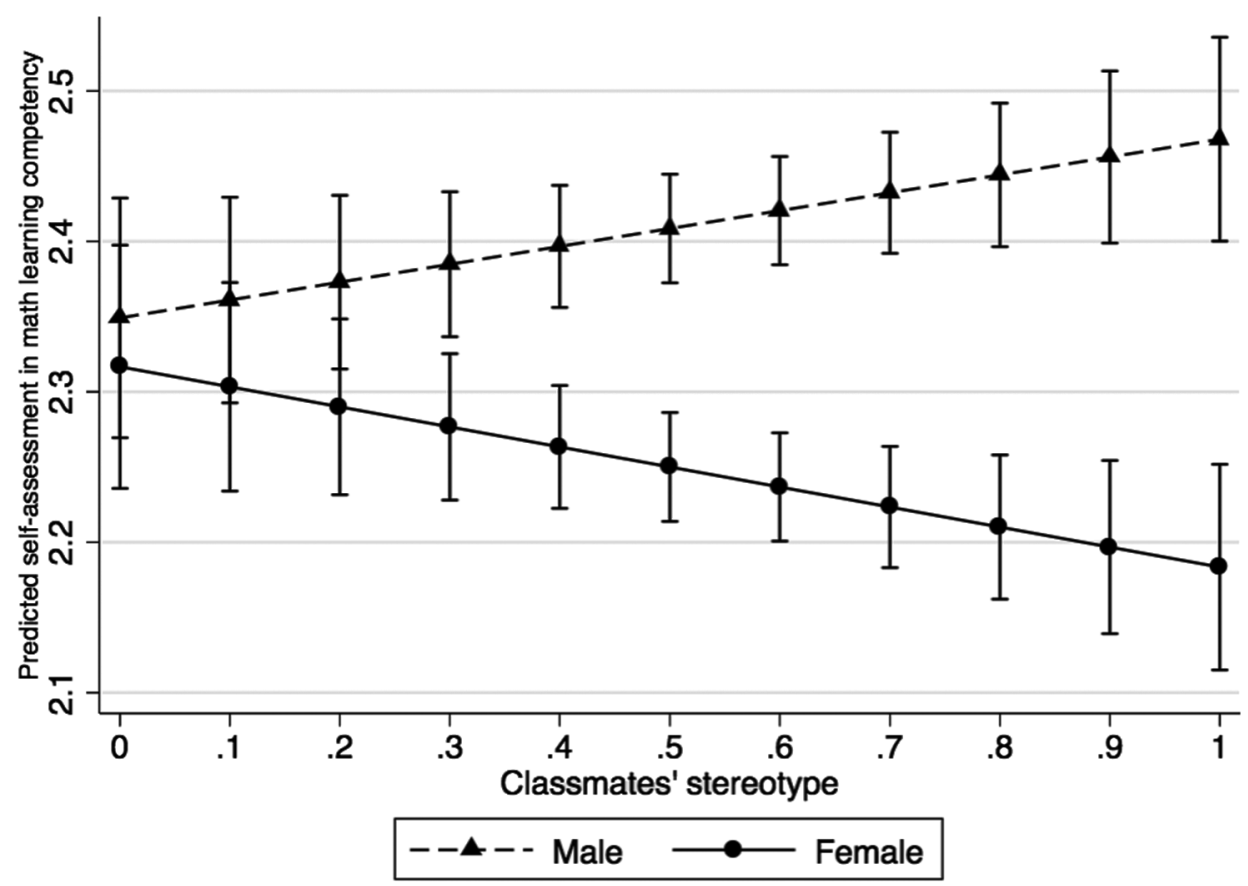

FIG. 3.-Marginal effect of classmates' gender-math stereotype on self-assessment in math learning competency by gender with 95\% confidence level. SOURCE.-China Education Panel Survey (CEPS). This figure is based on model 4 of table 2.

assessment is positively correlated with aspiration in science and engineering in all models, indicating that students with higher math self-assessment are more likely to aspire to such careers. In addition, model 2 shows a significantly positive interaction effect between gender and self-assessment ( $\beta=$ 0.331 ). This means that with increasing self-assessment in math, the likelihood of aspiring to science and engineering careers increases more rapidly for females than for males. Therefore, the gender gap in aspiration decreases as math self-assessment increases.

In models 3-6, none of the main stereotype variables shows statistically significant effect, indicating no stereotype effects among males. However, in model 3, the interaction term between student's stereotype and gender has a significant negative coefficient $(\beta=-0.395)$, showing that the gender difference in the log odds of aspiration is larger among students who endorse the gender-math stereotype $(\beta=-1.871-0.395=-2.266)$ compared to students who do not endorse such stereotype $(\beta=-1.871)$. The other two interaction terms in models 4 and 5 do not exhibit significant effects, indicating that the gender gap in students' aspiration in science and engineering careers do not vary according to parents' or classmates' stereotypes. 
TABLE 3

Random Effects Logistic Regression Models Predicting Aspiration in Science and Engineering

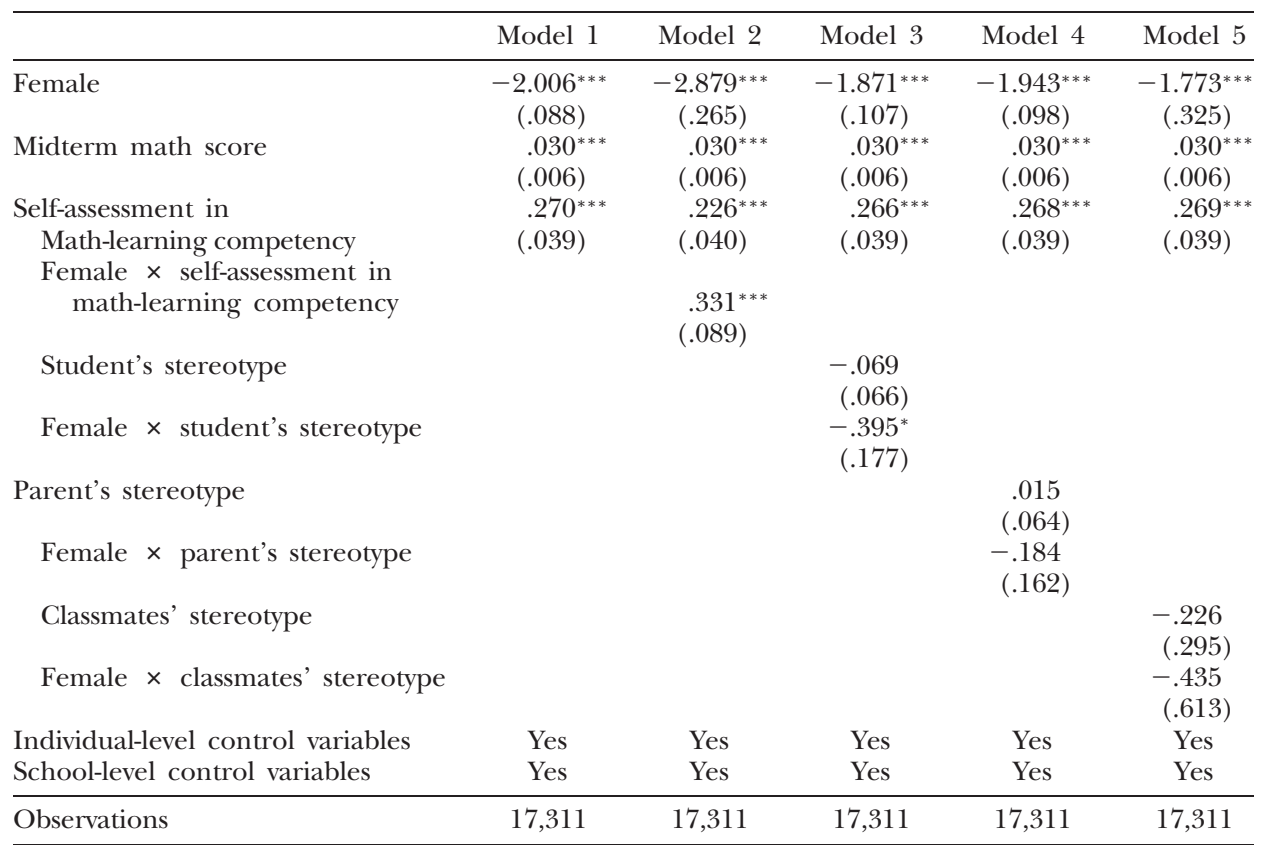

Note.-Standard errors in parentheses. Model 1 is the base model with female, midterm math score, and selfassessment in math learning competency as the independent variables; model 2 adds the interaction between female and self-assessment to model 1; model 3 adds student's stereotype and its interaction with female to model 1; model 4 adds parent's stereotype and its interaction with female to model 1; model 5 adds classmate's stereotype and its interaction with female to model 1 . Control variables at the individual and school level are included in all models but omitted from the table.

Source.-China Education Panel Survey (CEPS). Dependent variable is students' aspiration in science and engineering careers. Individual-level survey weights are used in all models.

${ }^{*} P<.05$.

** $P<.01$.

*** $P<.001$.

Moreover, after adding the stereotype variables, the effect of gender only slightly decreases but remains significant, indicating that even among students who are not exposed to the gender-math stereotype, girls are still less likely to aspire to becoming scientists or engineers than boys. This means that the effect of math self-assessment and gender-math stereotypes do not explain away the significant gender gap in students' career aspiration.

\section{Discussion and Limitation}

Results from the analysis first demonstrate a significant gender gap in Chinese middle school students' aspiration in science and engineering: while 13.6 percent of boys exhibit early aspiration of becoming scientists and engineers, only 2.2 percent of girls have the same career aspiration. The huge gender gap in adolescents' career aspirations indicates possible gender differences in future career choices and segregation in the labor 
market. In addition, descriptive results demonstrate that the gender-math stereotype widely exists in the Chinese society. This is in line with the recent evidence of gender inequality and gendered cultural norms in contemporary China (Li and Lavely 2003; World Economic Forum 2015).

Second, extending the stereotype threat theory, this article finds that gender-math stereotypes from students, parents, and peers are associated with biased self-assessment in math-learning competency. Among students whose parents do not endorse the stereotype, the gender gap in self-assessment is smaller compared to students whose parents endorse the stereotype. Among students who do not endorse such stereotype themselves, the gender gap in self-assessment even favors females. For students in a class with fewer classmates endorsing the stereotype, the gender gap in math self-assessment is insignificant; the gender gap favoring males only emerges and expands when the percentage of classmates having such stereotype increases. Moreover, students' math self-assessment is significantly correlated with their aspiration in science and engineering careers.

Another important finding is that the effect of math performance on math self-assessment is stronger among boys than girls, indicating that the stereotypical environment may counteract the effect of positive performance feedback for girls. On the other hand, the effect of math self-assessment on science and engineering aspiration is stronger among girls than boys, indicating that when girls' self-assessment of math-learning competency increases, their aspiration in science and engineering grows faster than that of boys. This shows a promising way of reducing the gender gap in STEM aspiration by increasing girls' math self-assessment.

Filling the gaps in stereotype threat theory, this study shows how gender stereotype contributes to the gender gap in math self-assessment after controlling for math performance. However, contrary to findings in Correll (2001) with the US data, this study shows that even after controlling for math selfassessment and gender-math stereotype, boys are still more likely to aspire to careers in science and engineering than girls. This unexplained gender gap indicates that there must be other factors contributing to the gendered career paths in China. Previous comparative research shows that larger gender gaps in math are found in countries with lower gender equality in politics, education, and labor participation (Guiso, Monte, and Sapienza 2008; Else-Quest, Hyde, and Linn 2010). These structural constraints may be additional factors contributing to the gender gap in students' career aspirations in China.

This study has several limitations. First, as discussed in the methodology section, there is a possibility of reverse causation. The control of midterm math scores and cognitive ability tests helps alleviate the problem but does not completely solve it. A possible direction for future studies is to use longitudinal data and include lagged variables to control for students' selfassessment in a previous year. 
Second, the question about career aspirations in the CEPS survey has only 10 categories, and the "scientists and engineers" category does not distinguish between academic fields. Research has revealed an increasing proportion of female professionals in biology but a persisting lack of female representation in engineering and physical sciences (Jones et al. 2000). Future surveys and studies should include more detailed categorization of careers for a more accurate analysis.

Third, there is no measurement of teachers' gender-math stereotype in the CEPS survey. Previous studies show that when teachers view mathematics as a male domain, they tend to overrate male students' math capability and express more positive attitudes toward male students (Shepardson and Pizzini 1992; Leedy et al. 2003). Therefore, it is important for future surveys and studies to include teachers' beliefs and behaviors in the study of gendermath stereotypes.

\section{Conclusion and Implications}

The main contribution of this study is to extend stereotype threat theory by demonstrating how gender-math stereotype from students, parents, and peers correlates with biased self-assessment in math-learning competency, and how this biased self-assessment further affects students' career aspiration. The Chinese context provides a unique setting with a widespread gender stereotype and a female advantage in math performance and is therefore especially helpful for understanding the role of gender-math stereotype in the persistent gender gap in STEM aspiration. Findings may also be transferred to other countries in explaining the underrepresentation of women in STEM fields, especially in countries with a similar level of gender-math stereotype.

Findings of this study have important implications for educational practices. First, it is crucial to raise awareness of gender-math stereotype in classrooms and its threat to girls' self-assessment. Schools should consider intervention programs that specially target reduction of gender-math stereotype among students (e.g., programs highlighting counter-stereotypical female role models in STEM fields). In addition, schools could enhance communication with parents and provide resources against the gender-math stereotype at home. Second, schools can provide psychological intervention to help increase female students' coping ability in a threatening environment (e.g., ensuring positive feedbacks to girls with good math performance and providing mentoring programs to girls interested in STEM fields).

Finally, it is important to reduce the gender-math stereotype in the larger society. Previous research shows that higher female employment in the research workforce is related to weaker gender-science stereotype (Miller et al. 2015). This means that a higher level of diversity in college and the labor 
market through affirmative action policies may not only directly increase females' opportunities in male-dominated fields but also helps to reduce gender stereotypes in society, thus encouraging more female students to pursue careers in fields that have been historically dominated by men.

\section{References}

Aguinis, Herman, Ryan K. Gottfredson, and Steven Andrew Culpepper. 2013. "Best-Practice Recommendations for Estimating Cross-Level Interaction Effects Using Multilevel Modeling." Journal of Management 39 (6): 1490-528.

Ayalon, Hanna, and Idit Livneh. 2013. "Educational Standardization and Gender Differences in Mathematics Achievement: A Comparative Study." Social Science Research 42 (2): 432-45.

Charles, Maria, and Karen Bradley. 2009. "Indulging Our Gendered Selves? Sex Segregation by Field of Study in 44 Countries." American Journal of Sociology 114 (4): 924-76.

Charles, Maria, Bridget Harr, Erin Cech, and Alexandra Hendley. 2014. "Who Likes Math Where? Gender Differences in Eighth-Graders' Attitudes around the World." International Studies in Sociology of Education 24 (1): 85-112.

Correll, Shelley J. 2001. "Gender and the Career Choice Process: The Role of Biased Self-Assessments.” American Journal of Sociology 106 (6): 1691-730.

Correll, Shelley J. 2004. "Constraints into Preferences: Gender, Status, and Emerging Career Aspirations.” American Sociological Review 69 (1): 93-113.

Croll, Elisabeth. 2000. Endangered Daughters: Discrimination and Development in Asia. London: Routledge.

Dweck, Carolyn S., and Therese E. Goetz. 1978. "Attributions and Learned Helplessness." New Directions in Attribution Research 2:157-79.

Eccles, Jacquelynne S., and Janis E. Jacobs. 1986. "Social Forces Shape Math Attitudes and Performance." Signs 11 (2): 367-80.

Eccles, Jacquelynne S., Janis E. Jacobs, and Rena D. Harold. 1990. "Gender Role Stereotypes, Expectancy Effects, and Parents' Socialization of Gender Differences." Journal of Social Issues 46 (2): 183-201.

Else-Quest, Nicole M., Janet Shibley Hyde, and Marcia C. Linn. 2010. "Cross-National Patterns of Gender Differences in Mathematics: A Meta-Analysis." Psychological Bulletin 136 (1): 103-27.

Good, Catherine, Joshua Aronson, and Jayne Ann Harder. 2008. "Problems in the Pipeline: Stereotype Threat and Women's Achievement in High-Level Math Courses." Journal of Applied Developmental Psychology 29 (1): 17-28.

Granrose, Cherlyn Skromme. 2007. "Gender Differences in Career Perceptions in the People's Republic of China." Career Development International 12 (1): 9-27.

Guiso, Luigi, Ferdinando Monte, Paola Sapienza, and Luigi Zingales. 2008. "Culture, Gender, and Math.” Science 320 (5880): 1164-65.

Hannum, Emily, Peggy Kong, and Yuping Zhang. 2009. "Family Sources of Educational Gender Inequality in Rural China: A Critical Assessment." International Journal of Educational Development 29 (5): 474-86. 
Hannum, Emily, and Yu Xie. 1994. "Trends in Educational Gender Inequality in China: 1949-1985." Research in Social Stratification and Mobility 13:73-98.

He, Guangye, and Xiaogang Wu. 2017. "Marketization, Occupational Segregation, and Gender Earnings Inequality in Urban China." Social Science Research 65 (July): 96-111.

Jones, Gail, Ann Howe, and Melissa J. Rua. 2000. "Gender Differences in Students' Experiences, Interests, and Attitudes toward Science and Scientists." Science Education 84 (2): 180-92.

Leedy, M. Gail, Donna LaLonde, and Kristen Runk. 2003. "Gender Equity in Mathematics: Beliefs of Students, Parents, and Teachers." School Science and Mathematics 103 (6): 285-92.

Li, Jianghong, and William Lavely. 2003. "Village Context, Women's Status, and Son Preference among Rural Chinese Women.” Rural Sociology 68 (1): 87-106.

Liu, Fengshu. 2014. "From Degendering to (Re) gendering the Self: Chinese Youth Negotiating Modern Womanhood." Gender and Education 26 (1): 18-34.

Lueptow, Lloyd B., Lori Garovich-Szabo, and Margaret B. Lueptow. 2001. "Social Change and The Persistence of Sex Typing: 1974-1997." Social Forces 80 (1): 1-36.

Mann, Allison, and Thomas A. DiPrete. 2016. "The Consequences of the National Math and Science Performance Environment for Gender Differences in STEM Aspiration." Sociological Science 3 (30): 568-603.

Mann, Allison, Joshua Legewie, and Thomas A. DiPrete. 2015. "The Role of School Performance in Narrowing Gender Gaps in the Formation of STEM Aspirations: A Cross-National Study." Frontiers in Psychology 6 (February): article 171.

Maple, Sue A., and Frances K. Stage. 1991. "Influences on the Choice of Math/Science Major by Gender and Ethnicity." American Educational Research Journal 28 (1): 37-60.

Miller, David I., Alice H. Eagly, and Marcia C. Linn. 2015. "Women's Representation in Science Predicts National Gender-Science Stereotypes: Evidence from $66 \mathrm{Na}$ tions." Journal of Educational Psychology 107 (3): 631-44.

Mullis, Ina V. S., Michael O. Martin, and Tom Loveless. 2015. 20 Years of TIMSS: International Trends in Mathematics and Science Achievement, Curriculum, and Instruction. Presented at the TIMSS and PIRLS International Study Center.

National Science Foundation. 2016. Science and Engineering Indicators 2016. Alexandria, VA: National Science Board.

Nguyen, Hannah-Hanh D., and Ann Marie Ryan. 2008. "Does Stereotype Threat Affect Test Performance of Minorities and Women? A Meta-Analysis of Experimental Evidence." Journal of Applied Psychology 93 (6): 1314-34.

Nosek, Brian A., Frederick L. Smyth, N. Sriram, Nicole M. Lindner, Thierry Devos, Alfonso Ayala, Yoav Bar-Anan, et al. 2009. "National Differences in Gender-Science Stereotypes Predict National Sex Differences in Science and Math Achievement." Proceedings of the National Academy of Sciences of the USA 106 (26): 10593-97.

OECD. 2014. PISA 2012 Technical Report. Paris: OECD.

OECD. 2015. The ABC of Gender Equality in Education: Aptitude, Behavior, Confidence. Paris: OECD.

Perry, Brea L., Tanja Link, Christina Boelter, and Carl Leukefeld. 2012. "Blinded to Science: Gender Differences in the Effects of Race, Ethnicity, and Socio- 
economic Status on Academic and Science Attitudes among Sixth Graders.” Gender and Education 24 (7): 725-43.

Riegle-Crumb, Catherine, Chelsea Moore, and Aida Ramos-Wada. 2011. "Who Wants to Have a Career in Science or Math? Exploring Adolescents' Future Aspirations by Gender and Race/Ethnicity." Science Education 95 (3): 458-76.

Schunk, Dale H. 1987. "Peer Models and Children's Behavioral Change." Review of Educational Research 57 (2): 149-74.

Shepardson, Daniel P., and Edward L. Pizzini. 1992. "Gender Bias in Female Elementary Teachers' Perceptions of the Scientific Ability of Students." Science Education 76 (2): 147-53.

Sikora, Joanna, and Artur Pokropek. 2012. "Gender Segregation of Adolescent Science Career Plans in 50 Countries." Science Education 96 (2): 234-64.

Spencer, Steven J., Claude M. Steele, and Diane M. Quinn. 1999. "Stereotype Threat and Women's Math Performance." Journal of Experimental Social Psychology 35 (1): 4-28.

Steele, Claude M., and Joshua Aronson. 1995. "Stereotype Threat and the Intellectual Test Performance of African Americans." Journal of Personality and Social Psychology 69 (5): 797-811.

Summerfield, Gale, Xiao-Yuan Dong, Nahid Aslanbeigui, and Jie Hu. 2011. "Wage Differentials, Occupational Segregation, and Gendered Creativity Perceptions in the Chinese Science and Technology Sector: Beijing and Wuhan." Eastern Economic Journal 37 (2): 178-96.

Thoman, Dustin B., Paul H. White, Niwako Yamawaki, and Hirofumi Koishi. 2008. "Variations of Gender-Math Stereotype Content Affect Women's Vulnerability to Stereotype Threat." Sex Roles 58 (9-10): 702-12.

Trusty, Jerry, Kok-Mun Ng, and Maximino Plata. 2000. "Interaction Effects of Gender, SES, and Race-Ethnicity on Postsecondary Educational Choices of US Students." Career Development Quarterly 49 (1): 45-59.

Tsui, Ming. 2007. "Gender and Mathematics Achievement in China and the United States." Gender Issues 24 (3): 1-11.

Williams, John E., and Deborah L. Best. 1990. Measuring Sex Stereotypes: A Multination Study. Beverly Hills, CA: Sage.

World Economic Forum. 2015. The Global Gender Gap Report 2015. Cologny: World Economic Forum.

Xie, Yu, and Kimberlee A. Shauman. 2003. Women in Science: Career Processes and Outcomes. Vol. 26. Cambridge, MA: Harvard University Press.

Xiu, Lin, and Morley Gunderson. 2015. "Occupational Segregation and the Gender Earnings Gap in China: Devils in the Details." International Journal of Manpower 36 (5): 711-32. 